University of Nebraska - Lincoln

DigitalCommons@University of Nebraska - Lincoln

Agronomy \& Horticulture - Faculty Publications

Agronomy and Horticulture Department

2018

\title{
Maize and soybean root front velocity and maximum depth in Iowa, USA
}

\author{
Raziel A. Ordóñez \\ lowa State University, ordonez@iastate.edu \\ Michael J. Castellano \\ lowa State University, castelmj@iastate.edu
}

J. L. Hatfield

United States Department of Agriculture Agricultural Research Service, jerry.hatfield@ars.usda.gov

M. J. Helmers

lowa State University, mhelmers@iastate.edu

Mark A. Licht

lowa State University, lichtma@iastate.edu

See next page for additional authors

Follow this and additional works at: https://digitalcommons.unl.edu/agronomyfacpub

Part of the Agricultural Science Commons, Agriculture Commons, Agronomy and Crop Sciences Commons, Botany Commons, Horticulture Commons, Other Plant Sciences Commons, and the Plant Biology Commons

Ordóñez, Raziel A.; Castellano, Michael J.; Hatfield, J. L.; Helmers, M. J.; Licht, Mark A.; Liebman, Matt; Dietzel, Ranae; Martinez-Feria, Rafael; Iqbal, Javed; Puntel, Laila A.; Córdova, S. Carolina; Togliatti, Kaitlin; Wright, Emily E.; and Archontoulis, Sotirios V., "Maize and soybean root front velocity and maximum depth in lowa, USA" (2018). Agronomy \& Horticulture -- Faculty Publications. 1248.

https://digitalcommons.unl.edu/agronomyfacpub/1248

This Article is brought to you for free and open access by the Agronomy and Horticulture Department at DigitalCommons@University of Nebraska - Lincoln. It has been accepted for inclusion in Agronomy \& Horticulture -Faculty Publications by an authorized administrator of DigitalCommons@University of Nebraska - Lincoln. 


\section{Authors}

Raziel A. Ordóñez, Michael J. Castellano, J. L. Hatfield, M. J. Helmers, Mark A. Licht, Matt Liebman, Ranae Dietzel, Rafael Martinez-Feria, Javed Iqbal, Laila A. Puntel, S. Carolina Córdova, Kaitlin Togliatti, Emily E. Wright, and Sotirios V. Archontoulis 


\title{
Maize and soybean root front velocity and maximum depth in Iowa, USA
}

\author{
Raziel A. Ordóñez ${ }^{\mathrm{a}, *}$, Michael J. Castellano ${ }^{\mathrm{a}}$, Jerry L. Hatfield ${ }^{\mathrm{b}}$, Matthew J. Helmers ${ }^{\mathrm{c}}$, \\ Mark A. Licht ${ }^{a}$, Matt Liebman ${ }^{a}$, Ranae Dietzel ${ }^{a}$, Rafael Martinez-Feria ${ }^{a}$, Javed Iqbal ${ }^{a}$, \\ Laila A. Puntel ${ }^{\mathrm{a}}$, S.Carolina Córdova ${ }^{\mathrm{a}}$, Kaitlin Togliatti ${ }^{\mathrm{a}}$, Emily E. Wright ${ }^{\mathrm{a}}$,
} Sotirios V. Archontoulis ${ }^{\mathrm{a}, *}$

a Department of Agronomy, Iowa State University, Agronomy Hall, Ames, IA 50011-1010, USA

b USDA-ARS, National Laboratory for Agriculture and the Environment, Ames, IA 50011, USA

c Department of Agricultural and Biosystems Engineering, Iowa State University, Elings Hall, Ames, IA 50011-3270, USA

\section{A R T I C L E I N F O}

\section{Keywords:}

Root depth

Root front velocity

Water table

Temperature

Modeling

\begin{abstract}
A B S T R A C T
Quantitative measurements of root traits can improve our understanding of how crops respond to soil and weather conditions, but such data are rare. Our objective was to quantify maximum root depth and root front velocity (RFV) for maize (Zea mays) and soybean (Glycine max) crops across a range of growing conditions in the Midwest USA. Two sets of root measurements were taken every 10-15 days: in the crop row (in-row) and between two crop rows (center-row) across six Iowa sites having different management practices such as planting dates and drainage systems, totaling 20 replicated experimental treatments. Temporal root data were best described by linear segmental functions. Maize RFV was $0.62 \pm 0.2 \mathrm{~cm} \mathrm{~d}^{-1}$ until the 5 th leaf stage when it increased to $3.12 \pm 0.03 \mathrm{~cm} \mathrm{~d}^{-1}$ until maximum depth occurred at the 18th leaf stage $\left(860{ }^{\circ} \mathrm{Cd}\right.$ after planting). Similar to maize, soybean RFV was $1.19 \pm 0.4 \mathrm{~cm} \mathrm{~d}^{-1}$ until the 3rd node when it increased to $3.31 \pm 0.5 \mathrm{~cm} \mathrm{~d}^{-1}$ until maximum root depth occurred at the 13 th node $\left(813.6{ }^{\circ} \mathrm{C} \mathrm{d}\right.$ after planting). The maximum root depth was similar between crops $(P>0.05)$ and ranged from 120 to $157 \mathrm{~cm}$ across 18 experimental treatments, and $89-90 \mathrm{~cm}$ in two experimental treatments. Root depth did not exceed the average water table (two weeks prior to start grain filling) and there was a significant relationship between maximum root depth and water table depth $\left(R^{2}=0.61 ; P=0.001\right)$. Current models of root dynamics rely on temperature as the main control on root growth; our results provide strong support for this relationship $\left(R^{2}>0.76\right.$; $P<0.001$ ), but suggest that water table depth should also be considered, particularly in conditions such as the Midwest USA where excess water routinely limits crop production. These results can assist crop model calibration and improvements as well as agronomic assessments and plant breeding efforts in this region.
\end{abstract}

\section{Introduction}

Root systems affect plant growth, crop yields, and soil health, but studies on root characteristics are sparse. For example, plant breeding programs have focused on the selection of above ground plant traits for yield improvement (Tollenaar et al., 2004; Tollenaar and Lee, 2006) while giving little attention to the below-ground root morphology (Lynch, 2007). Among many root traits, root front velocity (RFV) and maximum depth are important because they determine the amount of water and nitrogen available for plant growth, as well as the amount of water and nitrogen vulnerable to leaching (Dunbabin et al., 2003). Indeed, deep, rapid-growth root systems may reduce losses of highly soluble nutrients such as nitrate (Lynch, 2013) because RFV closely matches the rate of nitrate leaching (York and Lynch, 2015).
Three-way interactions among crop genotype, management and environment determine maximum depth, RFV, and the ability of roots to extract water and nutrients. Relevant environmental factors include weather conditions (Watt et al., 2006), soil temperature and moisture (Weaver, 1926; Wang and Smith, 2004), ground water table (Stanley et al., 1980; Logsdon et al., 2009), soil-type and texture (Dwyer et al., 1996, Ball-Coelho et al., 1998), and nutrient availability (Lynch, 2007; Comas et al., 2013; Soylu et al., 2014). Management factors include the amount, type, placement and timing of fertilizer inputs (Dietzel et al., 2015; Lazicki et al., 2016), irrigation (Wang et al., 2014), tillage (Kaspar et al., 1991; Dweyer et al., 1996), row configuration (Whish et al., 2015) and others. Genotype factors include species identity (Borg and Grimes 1986) as well as variability between cultivars (Kaspar et al., 1984; Borg and Grimes, 1986; Yu et al., 2014). The mechanisms by

\footnotetext{
* Corresponding authors.

E-mail addresses: ordonez@iastate.edu (R.A. Ordóñez), sarchont@iastate.edu (S.V. Archontoulis).
} 
which the above-mentioned factors affect root growth and final depth are complex, but soil conditions play a major role (Rich and Watt, 2013; Bao et al., 2014). For example, a compacted soil layer will reduce root growth, no matter if temperature or moisture are at optimum levels for root growth (Keating et al., 2003).

In a review study of 48 crops species, Borg and Grimes (1986) reported maximum root depths of $180-300 \mathrm{~cm}$ for maize, $150-200 \mathrm{~cm}$ for soybean, $150-300 \mathrm{~cm}$ for sorghum, $150-240 \mathrm{~cm}$ for rye, and $150-300 \mathrm{~cm}$ for wheat. The wide range reflects variable interactions among genotype, management and environment. The RFV exhibits similar variability: sorghum 2-4 $\mathrm{cm} \mathrm{d}^{-1}$ (Monteith, 1986; Robertson et al., 1993; Whish et al., 2005; Manschadi et al., 2008), maize 2.7-6 $\mathrm{cm} \mathrm{d}^{-1}$ (Taylor and Klepper, 1973; Dardanelli et al., 1997; Singh et al., 2010), soybean 3.5-4.5 $\mathrm{cm} \mathrm{d}^{-1}$ (Stone et al., 1976; Kaspar et al., 1984), 2-7 $\mathrm{cm} \mathrm{d}^{-1}$ for wheat and barley (Cohen and Tadmor, 1969) and chickpea $2.5-3.6 \mathrm{~cm} \mathrm{~d}^{-1}$ (Kashiwagi et al., 2015). This variability indicates that use of generic values (i.e., averages) for root parameters across environments may result in misleading agronomic assessments of plant and cropping system performance.

In the Midwest USA, recent work has shown major changes in above ground plant growth between new and old era cultivars (Duvick and Cassman, 1999; Ciampitti and Vyn, 2012). Our literature review for Iowa, USA revealed that information on root parameters has not been updated since the mid 1980s when management practices and plant traits were different than those used presently (Mason et al., 1982; Kaspar et al., 1984; Borg and Grimes, 1986). Iowa is a high production region in the USA $75 \%$ of the landscape is occupied with maize and soybean, which contribute $12-15 \%$ to national grain production; USDANASS, 2015) and is also a region with water quality challenges. Shallow water tables exist in this region (Zhang and Schilling, 2006; Schilling, 2007; Logsdon et al., 2009) and subsurface drainage systems have been installed in many Iowa fields to increase crop yields by removing excess water (Helmers et al., 2012). Improved knowledge about maize and soybean RFV and maximum depth could greatly assist agronomists and crop modelers in analyzing and designing sustainable cropping systems. In this study, we analyzed maize and soybean RFV and maximum root depth data from 20 field experiments covering six sites in Iowa. We asked the following questions:

1) What is the RFV and maximum depth of maize and soybeans crops?

2) How much time does it take roots to occupy the space between rows and reach their maximum depth?

3) To what degree can we predict root depth over time and what is the best predictor among soil, crop and weather variables?

4) Does the water table level affect maximum root depth?

We hypothesized that RFV would be different between maize and soybean crops given their different structures; maize has a fibrous root system, whereas soybean has taproot system (Feldman, 1994; Lersten and Carlson, 2004). We also hypothesized that air temperature could be a good predictor of root growth given its use in simulation models (Keating et al., 2003; Yang et al., 2017). Finally, we also hypothesized that shallow water tables inhibit root growth because the lack of oxygen reduces roots' ability to take up water and nutrients (Dickin and Wright, 2008; Florio et al., 2014).

\section{Materials and methods}

\subsection{Experimental sites}

In 2016, field experiments with maize and soybean were established at six Iowa sites spanning a broad range of temperature, precipitation and soil type (Figs. 1 and 2). Basic soil information for the sites is provided in Fig. 1. Three sites, Central-Ames, Northwest, and Southeast had different planting dates as a sub-factor; one site, Southeast, had different drainage systems as a sub-factor (with and without subsurface drainage), and two sites, Central-Kelley and Northeast, had no subfactors (Table 1). The combination of sites, crops, and management practices resulted in 20 experimental units (Table 1). Experimental plots were set in a maize after soybean rotation using local management practices and well adapted cultivars. Maize plots were fertilized before or at planting (about $168 \mathrm{~kg} \mathrm{~N} / \mathrm{ha}$ ) while soybean plots did not receive nitrogen fertilizer. Crops were growing without supplemental irrigation. Each treatment was replicated three times at each site except Southeast, which had two replications. The size of replicated plots varied among sites; range from 360 to $3600 \mathrm{~m}^{2}$, with the largest plots being in Northeast experimental site. Weeds, pest and diseases were suppressed by spraying herbicides, insecticides and fungicides when necessary.

\subsection{Root measurements}

The distance between crop rows was $76 \mathrm{~cm}$ (the conventional spacing in Midwest maize and soybean plantings) in all treatments and sites except Northeast soybean, for which row spacing was $25.4 \mathrm{~cm}$ (Exp. 14; Table 1). Root depth measurements were taken in the crop row (in-row) and in the center of two rows (center-row) approximately every 10-15 days from planting until maximum root depth was observed. In Southwest, Central-Kelley and Central-Ames measurements were made weekly while in Southeast, Northwest and Northeast every other week. On each sampling date, four sub-replicate measurements in each replicate were manually sampled using conventional $1.8 \times 41 \mathrm{~cm}$ steel soil probes. Extensions were attached to the probe to capture roots to $180 \mathrm{~cm}$ depth (Fig. S1, panel a). Root depth was recorded in the field as the maximum visible root tip depth (Fig. S1, panel b).

When the maximum root depth was achieved per treatment a $6.20 \times 120 \mathrm{~cm}$ hydraulic soil core probe with extensions to sample to $200 \mathrm{~cm}$ depth (Giddings Machine Company, Windsor CO, USA; Fig. S1, panel c) was used to validate manual samples in 16 out of the 20 treatments. In the lab, root depth for each core was recorded as the maximum visible root tip depth. Sampling areas were selected to avoid weed contamination and plot edges.

\subsection{Weather, crop, and soil measurements}

Maximum temperature, global solar radiation, and precipitation were recorded from network stations positioned at the border of each of the six experimental sites (Iowa Environmental Mesonet, IEM). Longterm (35-year) historical weather data were also available for each site.

All the experimental sites (except Northeast) were instrumented with Decagon (Pullman, WA, USA) soil moisture, temperature, and groundwater table sensors recording data every $30 \mathrm{~min}$. Moisture and temperature sensors were positioned at two depth $(15$ and $45 \mathrm{~cm})$ in each replication. Wells with groundwater table sensors were positioned at the borders of the experiments and were not replicated per treatment. Soil nitrogen measurements were taken from all replicated plots every two weeks $(0-30 \mathrm{~cm})$ and monthly $(30-60 \mathrm{~cm})$. In each replication, 10 sub-samples were taken from in-row and center-row positions and homogenized. Field-moist soil samples were analyzed for $\mathrm{NO}_{3}-\mathrm{N}$ and $\mathrm{NH}_{4}-\mathrm{N}$ concentrations (Hood-Nowotny et al., 2010).

Destructive above-ground crop sampling per replication was conducted approximately every two weeks. The sampling area for maize was $1.5 \mathrm{~m}^{2}$ and for soybean $1 \mathrm{~m}^{2}$. Plants were counted and cut at the ground level and analyzed to derive the following parameters: growth stage, leaf area index, maize leaf number, soybean node and pod number, biomass accumulation per plant tissue (leaf, stem, and storage organ including husk, cobs and kernels for maize, and pod and grains for soybeans), as well as carbon and nitrogen concentrations per plant tissue. Crop and soil sampling took place on the same day as root sampling. Therefore, crop and soil data were used to explore correlations between root depth and crop, soil, and weather variables (see below). 


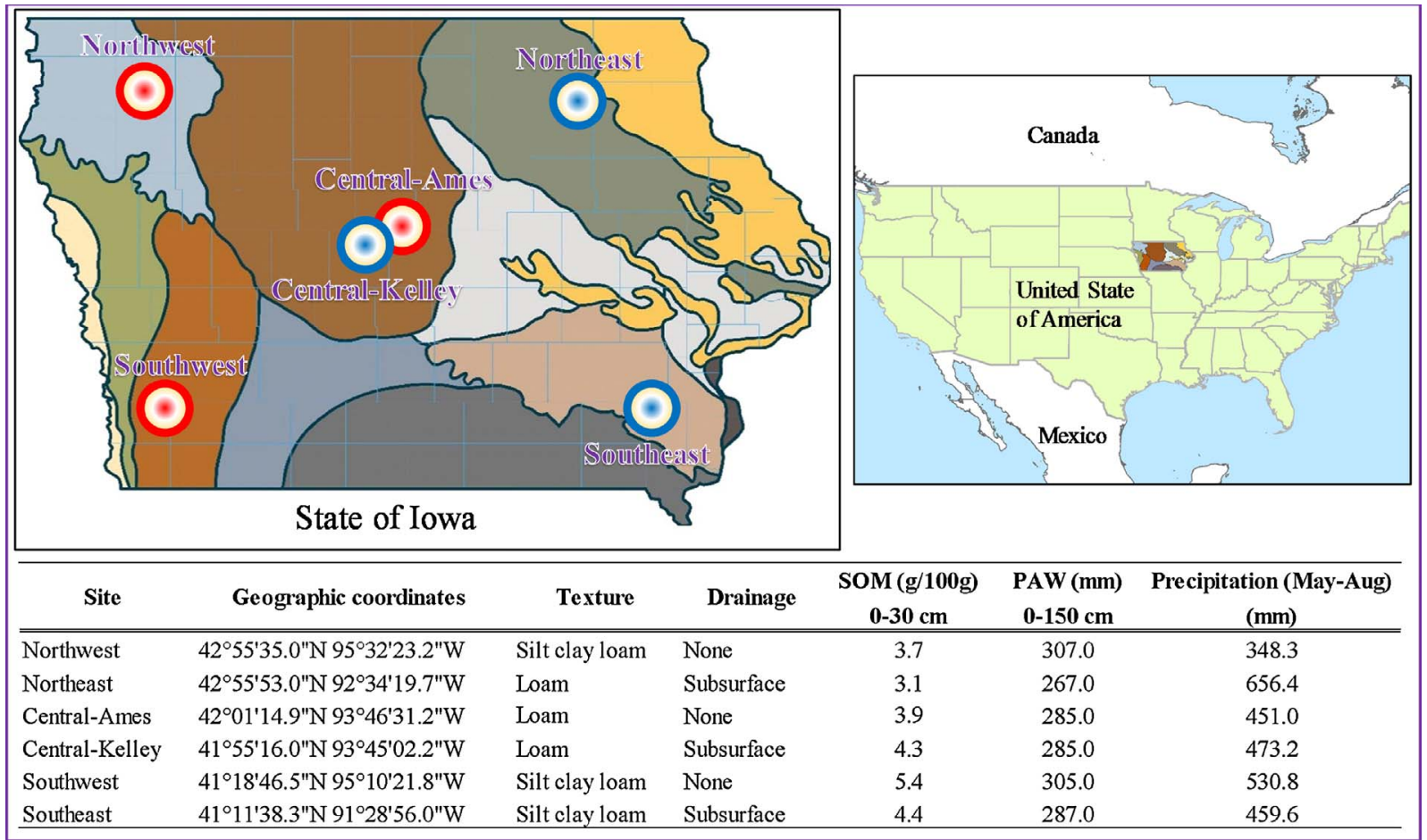

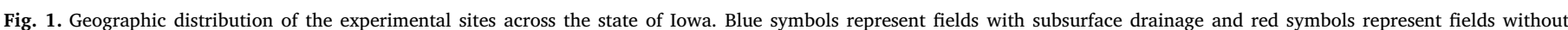

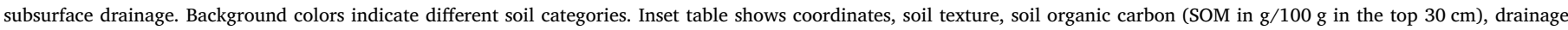

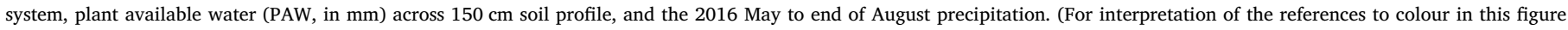
legend, the reader is referred to the web version of this article.)

Table 1

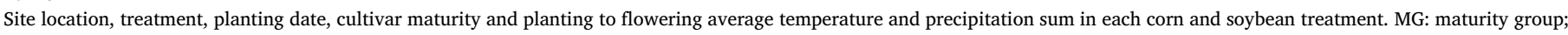
$\mathrm{CV}$ : coefficient of variation.

\begin{tabular}{|c|c|c|c|c|c|c|c|}
\hline \multirow[t]{2}{*}{ Location } & \multirow{2}{*}{$\begin{array}{l}\text { Exp. } \\
\text { ID }\end{array}$} & \multirow{2}{*}{$\begin{array}{l}\text { Symbol } \\
\text { (Figs. } 4 \text { and 6) }\end{array}$} & \multirow[t]{2}{*}{ Treatment } & \multirow{2}{*}{$\begin{array}{l}\text { Planting } \\
\text { Date }\end{array}$} & \multirow{2}{*}{$\begin{array}{l}\text { Cultivar } \\
\text { Maturity }\end{array}$} & \multicolumn{2}{|l|}{ Planting to flowering } \\
\hline & & & & & & Avg. Temperature $\left({ }^{\circ} \mathrm{C}\right)$ & Precipitation sum (mm) \\
\hline \multicolumn{8}{|c|}{ Corn experiments } \\
\hline Central-Ames & 1 & $(\mathbf{\Delta})$ & Early Planting & 26-Apr & 111-day & 19.6 & 224.5 \\
\hline Central-Ames & 2 & $(\Lambda)$ & Late Planting & 16-May & 111-day & 22.0 & 237.6 \\
\hline Central-Kelley & 3 & $(\bar{\star})$ & - & 18-May & 111-day & 22.5 & 239.5 \\
\hline Northeast & 4 & (米) & - & 23-Apr & 105-day & 18.5 & 483.6 \\
\hline Northwest & 5 & (O) & Early Planting & 7-May & 105-day & 19.9 & 259.4 \\
\hline Northwest & 6 & (O) & Late Planting & 1-Jun & 105-day & 22.4 & 174.6 \\
\hline Southwest & 7 & $(\diamond)$ & Early Planting & 26-Apr & 111-day & 19.4 & 390.6 \\
\hline Southwest & 8 & $(\diamond)$ & Late Planting & 15-May & 111-day & 21.8 & 321.7 \\
\hline Southeast & 9 & $(\square)$ & Subsurface Drainage & 13-May & 111-day & 21.9 & 192.6 \\
\hline \multirow[t]{3}{*}{ Southeast } & 10 & $(\square)$ & No subsurface drainage & 13-May & 111-day & 21.9 & 192.6 \\
\hline & & & & & Average & 21.0 & 271.7 \\
\hline & & & & & $C V \%$ & 6.9 & 36.4 \\
\hline \multicolumn{8}{|c|}{ Soybean experiments } \\
\hline Central-Ames & 11 & $(\Delta)$ & Early Planting & 6-May & 2.7 MG & 20.6 & 118.6 \\
\hline Central-Ames & 12 & $(\vec{\Delta})$ & Late Planting & 3-Jun & $2.7 \mathrm{MG}$ & 23.5 & 184.3 \\
\hline Central-Kelley & 13 & $(+)$ & - & 18-May & $2.7 \mathrm{MG}$ & 22.4 & 100.5 \\
\hline Northeast & 14 & (*) & - & 26-Apr & $1.9 \mathrm{MG}$ & 17.4 & 375.9 \\
\hline Northwest & 15 & (O) & Early Planting & 7-May & $2.2 \mathrm{MG}$ & 19.5 & 166.4 \\
\hline Northwest & 16 & (O) & Late Planting & 1-Jun & $2.2 \mathrm{MG}$ & 22.3 & 109.8 \\
\hline Southwest & 17 & $(\Delta)$ & Early Planting & 5-May & $3.1 \mathrm{MG}$ & 20.3 & 231.7 \\
\hline Southwest & 18 & $(\diamond)$ & Late Planting & 20-May & 3.1 MG & 22.5 & 194.8 \\
\hline Southeast & 19 & (口) & Subsurface Drainage & 22-May & $3.1 \mathrm{MG}$ & 23.3 & 90.2 \\
\hline \multirow[t]{3}{*}{ Southeast } & 20 & $(\square)$ & No subsurface drainage & 22-May & $3.1 \mathrm{MG}$ & 23.3 & 90.2 \\
\hline & & & & & Average & 21.6 & 171.5 \\
\hline & & & & & $C V \%$ & 9.7 & 53.8 \\
\hline
\end{tabular}

\subsection{Data analysis}

To detect differences between crops, management and site treatments $(n=20$; Table 1 ) a randomized complete block analysis of variance (ANOVA) was performed. For the four sites that had different management practices (Table 1) a split-plot ANOVA was performed to detect differences between crops and management factors. Crops and management factors were the fixed effects and the site was the random 
effect. Within each crop, we performed a second statistical analysis and calculated the Tukey's test to determine statistical significant difference among mean values for all studied root attributes. The statistical analysis was implemented using SAS 9.4 statistical package (SAS institute Inc., Cary, NC, US).

Linear and non-linear regression models were explored to fit root depth data over time and identify correlations between root depth and soil, crop, and weather variables (Archontoulis and Miguez, 2015). Linear, bi-linear and tri-linear segmental functions were selected to describe the progress of root elongation over time based on three criteria: determination coefficient $\left(R^{2}\right)$, meaning of parameters, and ability to provide answers to specific objectives. The following bi-and tri-linear equations were used to calculate root parameters:

$y=a+b x(x \leq c)+b c(x>c)+d(x-c)(x>c)$

$y=a+b x(x \leq c)+b c(x>c)+d(x-c)(x>c)+\mathrm{d} e(x-d)$

where $y$ is the root depth in $\mathrm{cm}, x$ is the time in days, $b$ is the initial RFV in $\mathrm{cm} \mathrm{d}^{-1}, d$ is the second phase RFV in $\mathrm{cm} \mathrm{d}^{-1}$, and $c$ is the breakpoint between $b$ and $d$; $e$ the break point between $d$ and $f$, and finally $f$ is a plateau indicating the time when root elongation ceased. In a few cases, where the root elongation did not show a plateau (Exps. 5, 6, 15, 16; Table 2; due to limited measurements), linear regression was used:

$y=a+b x(x \leq c)$

To identify variables that can predict root elongation we fitted nonlinear models between root elongation and explanatory variables and then a combination of statistical indexes $\left(R^{2}\right.$; Archontoulis and Miguez, 2015) to identify best predictors. The explanatory variables used in this analysis were: plant height, leaf number in maize, node number in soybean, leaf area index, plant biomass, thermal time (see below), cumulative rainfall and radiation since planting. Data analysis, model fitting and parameter estimation was done in GraphPad Prism 7.02 (GraphPad Software, Inc. San Diego, CA, USA). Thermal time was calculated as:

$\mathrm{GDD}=0.5^{*}(\mathrm{Tmax}+\mathrm{Tmin})-\mathrm{Tb}$

where GDD is the cumulative growing degree days since planting $\left({ }^{\circ} \mathrm{C} \mathrm{d}\right)$, Tmax and Tmin is the maximum and minimum daily air temperature $\left({ }^{\circ} \mathrm{C}\right)$, and $\mathrm{Tb}$ is the base temperature. A base temperature of $8{ }^{\circ} \mathrm{C}$ was used for both crops (Ritchie and NeSmith, 1991; Wu et al., 2015).

\section{Results}

\subsection{Weather and soil conditions}

Compared to 35-year average weather conditions, the six experimental sites experienced a wide range of weather in 2016 (Fig. 1). Four sites had below average precipitation from June to mid-July, a period of rapid root growth (Fig. 2a). All sites were warmer than average until mid-July and cooler until the end of August, except for Northeast (Fig. 2b). Plant available soil moisture in the top $60 \mathrm{~cm}$ ranged from 120 to $240 \mathrm{~mm}$ across sites and temporal dynamics followed precipitation patterns (Fig. 2d). Soil temperature rapidly increased from May $1\left(\sim 10{ }^{\circ} \mathrm{C}\right)$ to middle of June $\left(\sim 23^{\circ} \mathrm{C}\right)$ and fluctuated at that level until the end of August (Fig. 2e). Soil nitrate followed the same temporal patterns across sites, with high soil nitrate levels around the end of May and low nitrate levels in August (Fig. 2f).

Table 2

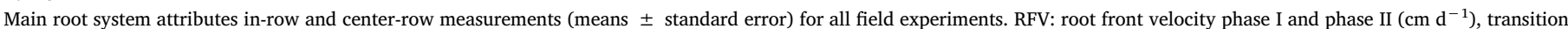
from phase I to phase II (days), maximum depth $(\mathrm{cm})$, root ceased (days) and coefficient of determination $\mathrm{R}^{2}$. CV: coefficient of variation.

\begin{tabular}{|c|c|c|c|c|c|c|c|c|c|c|c|}
\hline \multirow[t]{2}{*}{ Location } & \multirow[t]{2}{*}{ Exp. ID } & \multicolumn{6}{|c|}{ In-row measurements } & \multicolumn{4}{|c|}{ Center of two row measurements } \\
\hline & & $\begin{array}{l}\text { RVF Phase I } \\
\left(\mathrm{cm} \mathrm{d}^{-1}\right)\end{array}$ & $\begin{array}{l}\text { RFV Phase II } \\
\left(\mathrm{cm} \mathrm{d}^{-1}\right)\end{array}$ & $\begin{array}{l}\text { Transition Phase I to II } \\
\text { (days) }\end{array}$ & $\begin{array}{l}\text { Max Depth } \\
(\mathrm{cm})\end{array}$ & $\begin{array}{l}\text { Root ceased } \\
\text { (days) }\end{array}$ & $\mathrm{R}^{2}$ & $\begin{array}{l}\text { RFV Phase II } \\
\left(\mathrm{cm} \mathrm{d}^{-1}\right)\end{array}$ & $\begin{array}{l}\text { Max Depth } \\
(\mathrm{cm})\end{array}$ & $\begin{array}{l}\text { Root ceased } \\
\text { (days) }\end{array}$ & $\mathrm{R}^{2}$ \\
\hline \multicolumn{12}{|c|}{ Corn Experiments } \\
\hline Central-Ames & 1 & $0.61 \pm 0.1$ & $3.13 \pm 0.1$ & $39.9 \pm 1.5$ & $154 \pm 4$ & $79.6 \pm 0.9$ & 0.99 & $3.56 \pm 0.2$ & $146 \pm 1$ & $78.7 \pm 1.4$ & 0.95 \\
\hline Central-Ames & 2 & $0.95 \pm 0.6$ & $2.98 \pm 0.2$ & $26.0 \pm 3.1$ & $142 \pm 1$ & $65.4 \pm 1.6$ & 0.97 & $3.58 \pm 0.3$ & $130 \pm 1$ & $61.2 \pm 1.9$ & 0.93 \\
\hline Central-Kelley & 3 & $0.80 \pm 0.3$ & $3.47 \pm 0.2$ & $26.4 \pm 2.1$ & $148 \pm 2$ & $57.6 \pm 1.3$ & 0.97 & $3.47 \pm 0.2$ & $136 \pm 2$ & $62.1 \pm 1.8$ & 0.93 \\
\hline Northeast & 4 & $0.32 \pm 0.1$ & $2.45 \pm 0.1$ & $47.8 \pm 3.9$ & $145 \pm 2$ & $87.5 \pm 3.9$ & 0.94 & $3.80 \pm 0.5$ & $141 \pm 1$ & $49.5 \pm 2.7$ & 0.88 \\
\hline Northwest & 5 & \multicolumn{2}{|c|}{$1.48 \pm 0.2$} & - & $133 \pm 2$ & $65.3 \pm 2.2$ & 0.81 & $2.05 \pm 0.2$ & $145 \pm 1$ & - & 0.91 \\
\hline Northwest & 6 & \multicolumn{2}{|c|}{$1.47 \pm 0.1$} & - & $89 \pm 1$ & $54.0 \pm 0.0$ & 0.95 & $1.46 \pm 0.1$ & $100 \pm 1$ & - & 0.99 \\
\hline Southwest & 7 & $0.77 \pm 0.1$ & $3.37 \pm 0.3$ & $42.6 \pm 2.6$ & $157 \pm 2$ & $77.5 \pm 1.5$ & 0.97 & $3.87 \pm 0.2$ & $155 \pm 5$ & $79.6 \pm 1.2$ & 0.98 \\
\hline Southwest & 8 & $0.47 \pm 0.3$ & $3.08 \pm 0.4$ & $33.5 \pm 5.0$ & $144 \pm 1$ & $71.8 \pm 2.8$ & 0.85 & $2.73 \pm 0.2$ & $148 \pm 9$ & $83.5 \pm 2.4$ & 0.94 \\
\hline Southeast & 9 & $0.58 \pm 0.2$ & $3.44 \pm 0.1$ & $30.5 \pm 4.1$ & $142 \pm 9$ & $65.5 \pm 4.4$ & 0.95 & $3.94 \pm 1.3$ & $132 \pm 8$ & $63.8 \pm 2.3$ & 0.97 \\
\hline Southeast & 10 & $0.47 \pm 0.0$ & $3.00 \pm 0.3$ & $27.1 \pm 3.1$ & $140 \pm 5$ & $67.0 \pm 5.0$ & 0.97 & $2.78 \pm 0.3$ & $129 \pm 1$ & $70.3 \pm 2.8$ & 0.91 \\
\hline Average & & $0.62 \pm 0.2$ & $3.12 \pm 0.3$ & $34.2 \pm 8.3$ & $139 \pm 2$ & $70.8 \pm 9.2$ & & $3.12 \pm 0.8$ & $137 \pm 2$ & $68.6 \pm 11$ & \\
\hline$C V \%$ & & 33.6 & 10.7 & 24.2 & 13.6 & 13.0 & & 27.0 & 11.3 & 16.8 & \\
\hline P-value & & 0.02 & $<0.001$ & $<0.001$ & $<0.001$ & $<0.001$ & & $<0.001$ & $<0.001$ & $<0.001$ & \\
\hline Tukey's test & & 0.54 & 0.32 & 3.27 & 16.96 & 4.76 & & 1.02 & 9.25 & 1.69 & \\
\hline \multicolumn{12}{|c|}{ Soybean Experiments } \\
\hline Central-Ames & 11 & $1.35 \pm 0.1$ & $3.88 \pm 0.4$ & $46.8 \pm 2.1$ & $146 \pm 1$ & $69.1 \pm 1.2$ & 0.98 & $4.58 \pm 0.3$ & $144 \pm 2$ & $71.0 \pm 1.1$ & 0.98 \\
\hline Central-Ames & 12 & $1.50 \pm 0.1$ & $2.67 \pm 0.0$ & $9.7 \pm 2.6$ & $140 \pm 7$ & $56.9 \pm 2.3$ & 0.96 & $2.70 \pm 0.1$ & $137 \pm 7$ & $73.0 \pm 0.0$ & 0.92 \\
\hline Central-Kelley & 13 & $1.25 \pm 0.2$ & $3.11 \pm 0.2$ & $28.9 \pm 3.7$ & $140 \pm 2$ & $60.1 \pm 1.7$ & 0.94 & $2.93 \pm 0.2$ & $143 \pm 2$ & $71.2 \pm 2.2$ & 0.92 \\
\hline Northeast & 14 & $0.42 \pm 0.2$ & $3.90 \pm 0.1$ & $47.2 \pm 2.1$ & $154 \pm 4$ & $77.9 \pm 1.1$ & 0.92 & $2.38 \pm 0.3$ & $156 \pm 7$ & $86.0 \pm 0.0$ & 0.82 \\
\hline Northwest & 15 & \multicolumn{2}{|c|}{$1.20 \pm 0.1$} & - & $120 \pm 1$ & $84.0 \pm 0.0$ & 0.96 & $1.79 \pm 0.0$ & $136 \pm 2$ & - & 0.91 \\
\hline Northwest & 16 & \multicolumn{2}{|c|}{$1.42 \pm 0.1$} & - & $88 \pm 1$ & $54.0 \pm 0.0$ & 0.98 & $2.90 \pm 0.4$ & $81 \pm 14$ & - & 0.67 \\
\hline Southwest & 17 & $1.66 \pm 0.5$ & $2.89 \pm 0.3$ & $30.2 \pm 5.1$ & $156 \pm 6$ & $61.3 \pm 2.2$ & 0.93 & $3.50 \pm 0.3$ & $156 \pm 6$ & $63.5 \pm 2.0$ & 0.93 \\
\hline Southwest & 18 & $1.02 \pm 0.7$ & $3.17 \pm 0.2$ & $20.1 \pm 4.8$ & $142 \pm 1$ & $57.3 \pm 1.8$ & 0.93 & $3.06 \pm 0.4$ & $141 \pm 9$ & $60.7 \pm 3.0$ & 0.86 \\
\hline Southeast & 19 & $1.32 \pm 0.3$ & $3.89 \pm 0.0$ & $21.8 \pm 3.5$ & $134 \pm 4$ & $58.0 \pm 3.1$ & 0.97 & $3.45 \pm 0.3$ & $127 \pm 8$ & $70.8 \pm 2.8$ & 0.94 \\
\hline Southeast & 20 & $1.00 \pm 0.2$ & $2.99 \pm 0.3$ & $34.0 \pm 4.9$ & $135 \pm 8$ & $56.7 \pm 7.2$ & 0.98 & $3.20 \pm 0.2$ & $126 \pm 4$ & $75.5 \pm 2.3$ & 0.96 \\
\hline Average & & $1.19 \pm 0.4$ & $3.31 \pm 0.5$ & $33.3 \pm 10$ & $136 \pm 2$ & $62.1 \pm 7.5$ & & $3.25 \pm 0.7$ & $135 \pm 2$ & $71.5 \pm 7.7$ & \\
\hline CV\% & & 32.1 & 15.12 & 30.6 & 14.3 & 16.4 & & 24.3 & 16 & 10.7 & \\
\hline P-value & & 0.01 & $<0.001$ & $<0.001$ & $<0.001$ & $<0.001$ & & $<0.001$ & $<0.001$ & $<0.001$ & \\
\hline Tukey's test & & 0.66 & 0.51 & 6.98 & 5.45 & 4.23 & & 0.37 & 3.69 & 11.16 & \\
\hline
\end{tabular}

"Root data from the Northwest site were excluded from average and CV calculations. 

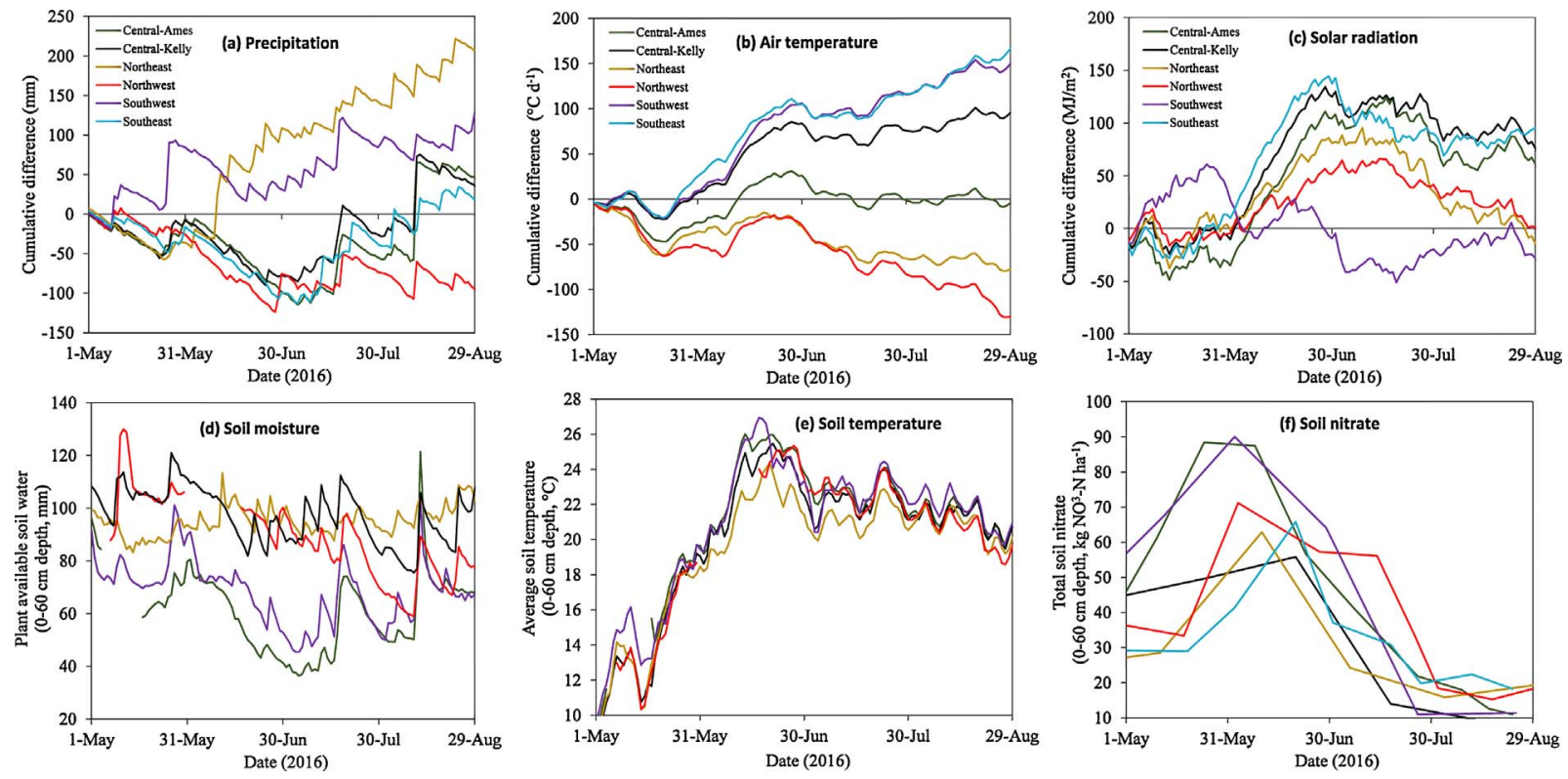

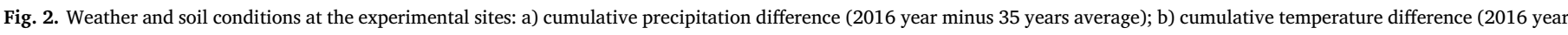

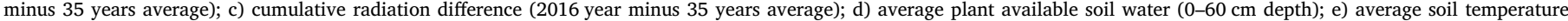

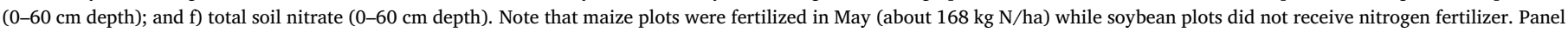
2f illustrates the average soil nitrate from the two crops.

\subsection{What is the rate of RFV and maximum depth?}

\subsubsection{Root front velocity}

In-row root elongation measurements showed a tri-linear pattern over time with an initial low rate (phase I) until 34 days after planting, followed by a fast rate (phase II) until 67 days after planting when the maximum depth was observed (Fig. 3; Table 2). The change in rate occurred at approximately 4.4 visible leaves for maize and 2.7 nodes for soybean. Root elongation rates for the center-row position followed a bi-linear increase, with a constant (fast) rate of increase followed by a plateau. Fig. 3 illustrates these temporal dynamics in two out of the 20 experimental units and Table 2 shows the parameters for all treatments.

During the initial phase, the in-row RFV ranged from 0.32 to $0.95 \mathrm{~cm} \mathrm{~d}^{-1}$ for maize, and from 0.42 to $1.66 \mathrm{~cm} \mathrm{~d}^{-1}$ for soybean across 16 treatments (Table 2 , see values in $\mathrm{cm}^{\circ} \mathrm{Cd}^{-1}$ in Table S1). Treatment had a significant effect on the RFV during the initial phase
( $P=0.002)$ but not during the second phase $(P=0.36)$. In the second phase RFV values ranged from 2.45 to $3.47 \mathrm{~cm} \mathrm{~d}^{-1}$ for maize and from 2.67 to $3.90 \mathrm{~cm} \mathrm{~d}^{-1}$ for soybeans (Table 2). On average, across all experiments, our results indicate that soybean roots grew $48 \%$ faster than maize during the first phase (Table 2). The center-row RFV ranged from 1.46 to $3.94 \mathrm{~cm} \mathrm{~d}^{-1}$ for maize, and from 1.79 to $4.58 \mathrm{~cm} \mathrm{~d}^{-1}$ for soybean, or from 0.13 to $0.24{ }^{\circ} \mathrm{C} \mathrm{d}^{-1}$ for maize and from 0.15 to $0.26{ }^{\circ} \mathrm{C}$ $\mathrm{d}^{-1}$ for soybean across experiments (Table 2 , and S1).

\subsubsection{Maximum root depth}

Across all treatments $(n=20)$, the maximum root depth ranged from $89 \pm 11$ to $157 \pm 3 \mathrm{~cm}$ for maize and from $89 \pm 12$ to $156 \pm 6 \mathrm{~cm}$ for soybean (Table 2). These variations were consistent in both sampling points, in-row and center-row. A statistical analysis considering all combinations of 20 treatments (site, crop and management) as independent treatments indicated significant differences (a)

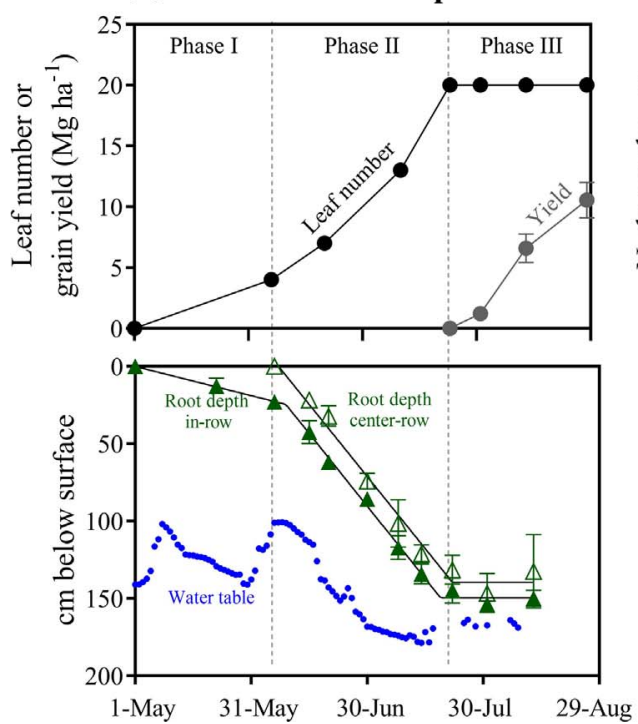

(b) Soybean - Exp. 19

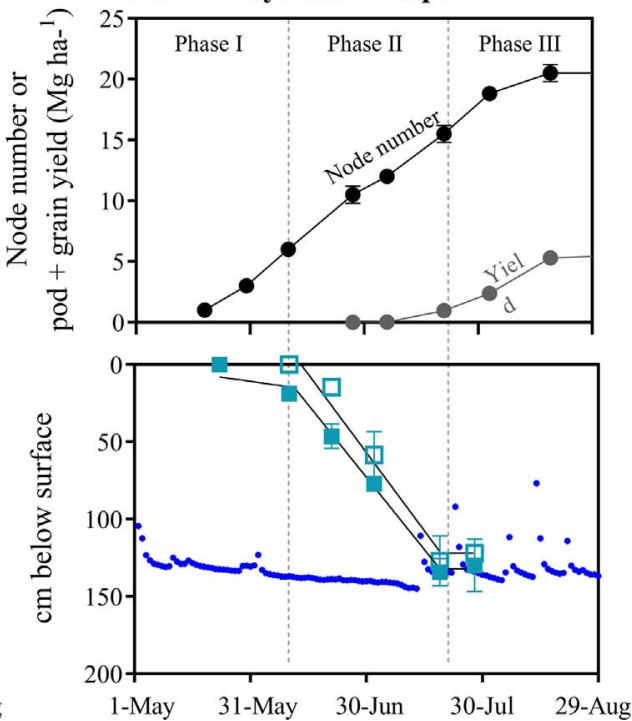

Fig. 3. Above- and below-ground plant characteristics and water table measurements in field experiment number 1 (maize) and 19 (soybean). Bottom panels: root depth measurements (triangles and squares), regression model fits to the root measurements (black lines) and water table dynamics (blue circles). Top panels: Leaf or node number (black symbols) and grain or fruit dry matter accumulation (grey symbols). Vertical broken lines illustrate the different phases observed in maize and soybean root growth. (For interpretation of the references to colour in this figure legend, the reader is referred to the web version of this article.) 


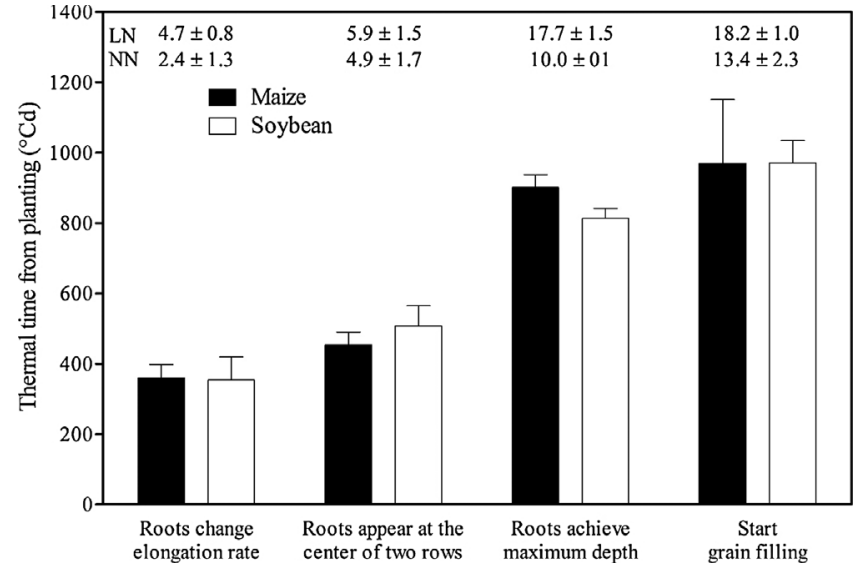

Fig. 4. Thermal time requirements for key root phenological events. Maize leaf number (LN) and soybean node number (NN) are shown. Data are average over 8 soybeans and 8 maize treatments (Northwest site treatments excluded). The error bars show the standard error of the mean values.

among them $(P=0.001$; Table S2). Within a site, statistical analysis indicated that there were significant differences in two of the three experiments in which different management treatments existed $(P=0.05)$, but not between crops (Table S3). In the Northwest, Central-Ames and Southwest sites, where planting date was a factor in the analysis, we observed a $29 \%, 9 \%$ and $5 \%$ reduction in maximum root depth in both crops due to late planting (Table 2). At the Southeast site, where drainage systems were a factor in the analysis, we did not observe any substantial variation in root depth (Table 2; Fig. 3b). Interestingly, root depth did not exceed the depth of groundwater table (Fig. 3b).

\subsection{How fast do roots occupy the center-row and when do they reach maximum depth?}

Roots reached the center-row at $42 \pm 0.4$ days after planting, equivalent to $480 \pm 29^{\circ} \mathrm{C} \mathrm{d}$ (Fig. 4). The variation among crops and treatments was small (coefficient of variation 20.4\%). In the only experiment where row-to-row spacing was $25.4 \mathrm{~cm}$ (Table 1; Exp. ID: 14) the time requirement to cover the space between two rows was 9 days. Maximum root depth was achieved about 70 days after planting for maize and 9 days earlier in soybean (Figs. 4 and S4; Table 2). In both crops root elongation ceased and maximum depth was observed about 10 days prior to start of grain filling (Fig. 4 and S4).

\subsection{To what degree can we predict root depth and which is the best predictor among soil, crop and weather variables?}

Among six explanatory variables, thermal time was the best "easily measurable" estimator of root depth explaining $76-84 \%$ of the variation in both crops (Figs. 5 and S2, S3). Cumulative precipitation since planting was the worst estimator. Plant height explained $77-86 \%$ of the root depth variation, LAI explained $80-89 \%$ of the variation, leaf (maize) or node (soybean) number explained $84-90 \%$ of the variation, and above-ground biomass explained $84-90 \%$ of the variation. Following this exploratory analysis, root depth data were pooled by crop and measurement position (in-row versus center-row) to derive average predictive functions (Fig. 5). In this analysis, we fitted bi- and tri-linear models to derive biological meaningful parameters and the rates of increase per phase are provided in Fig. 5. Root elongation ceased at $886^{\circ} \mathrm{C} \mathrm{d}$ for maize and $816^{\circ} \mathrm{C} \mathrm{d}$ for soybean. The rate of root elongation in center-row measurements was lower and ceased later compared to the in-row measurements (Fig. 5).

\subsection{Root depth and water table}

Depth to water table explained a large amount of variation in maximum root depth $\left(R^{2}=0.61 ; P=0.0004\right.$ : Fig. 6$)$. The deeper the water table, the deeper maximum root depth. In this analysis, water table data was averaged for a period of two weeks prior to final root measurement date (beginning of grain filling period). That was necessary given the dynamic nature of water table in the soil. Across sites, the two-week average water table depth from the soil surface ranged from 79 to $214 \mathrm{~cm}$ (Fig. 6). The shallowest water table depth was observed in Southeast (plots without subsurface drainage) and the deepest was in Southwest site.

\section{Discussion}

Our destructive sampling approach to track roots captured interacting factors that the root system experiences under field conditions (Passioura, 2006; Paez-Garcia et al., 2015). By coupling root measurements with soil, crop and weather information, we were able to develop predictive functions (Fig. 5, S2 and S3) that could be used for root phenotyping in breeding programs where root growth has previously been largely ignored. Furthermore, results from this study that captured a range of environmental conditions using six sites and 20 treatments can inform crop model improvements, and assist agronomic and water quality assessments in the Midwest, USA.

\subsection{Root front velocity}

Our frequent in-season root depth observations revealed two distinct phases in root elongation for corn and soybean (Fig. 5), which is in line with previous observations for sorghum (Robertson et al., 1993) and sunflower (Meinke et al., 1991). Corn and soybean crops had different RFV values early in the season but about the same during the mid-season (Tables 2 and S1), in contrast to our listed hypothesis. Previous studies reported a constant RFV (Kaspar et al., 1984) most likely due to a lack of high-resolution measurements to reveal the break point or due to position of measurement (in-row vs center of two rows; Figs. 3 and 5). In one of our six sites where less frequent measurements were taken (Northwest; Table 1) we were unable to calculate two rates (Table 2). This means that a strategic sampling is needed to capture key root parameters; our study provides guidance for future measurements (Fig. 4).

Compared to the limited experimental information available in the literature our soybean RFV values were higher compared to data from Nebraska (1.2-1.5 $\mathrm{cm} \mathrm{d}^{-1}$; Torrion et al., 2012), Kansas $\left(1.5 \mathrm{~cm} \mathrm{~d}^{-1}\right.$; Mayaki et al., 1976) and Minnesota (1.7 $\mathrm{cm} \mathrm{d}^{-1}$; Allmaras et al., 1975), and lower compared to a glasshouse experiment $\left(3.5-4.35 \mathrm{~cm} \mathrm{~d}^{-1}\right.$; Kaspar et al., 1983). This variation is likely related to different genotype, management, and environmental conditions among studies, as well as the methodology used to determine RFV (resolution of measurements and position; see coefficient of variation in Table 2). Our maize RFV values were comparable with previous reported values of 2.56-2.91 $\mathrm{cm} \mathrm{d}^{-1}$ (Singh et al., 2010); and lie in the middle of previous estimates: 3-6 $\mathrm{cm} \mathrm{d}^{-1}$ (Taylor and Kepler, 1973; Dardanelli et al., 1997), $1.3 \mathrm{~cm} \mathrm{~d}^{-1}$ (Allmaras et al., 1975) and $1.1 \mathrm{~cm} \mathrm{~d}^{-1}$ (Cahn et al., 1989).

In crop modeling use of a constant thermal time downward movement rate is common (Boote et al., 2008; Hammer et al., 2009; Yang et al., 2017). Theoretically this means that crop models over-predict root elongation in early growth stages (Fig. 4) and under-predict root elongation in later growth stages. These over- and under-predictions will affect water and nitrogen stress responses (e.g. Corre-Hellou et al., 2007). Process-based models such as DSSAT, APSIM, RZWQM, HybridMaize, Adapt-N as well as commercial models are routinely used in this high production region to forecast crop yields (Morell et al., 2016), evaluate nitrogen rates to maize (Malone et al., 2010; Puntel et al., 
(a)

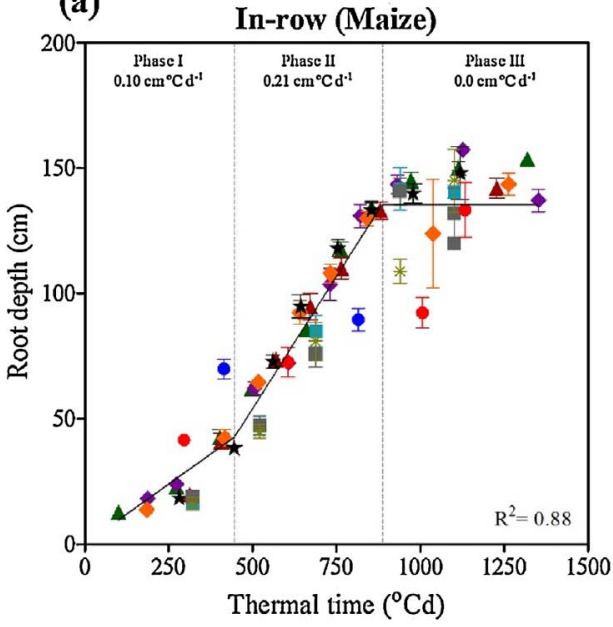

(c)

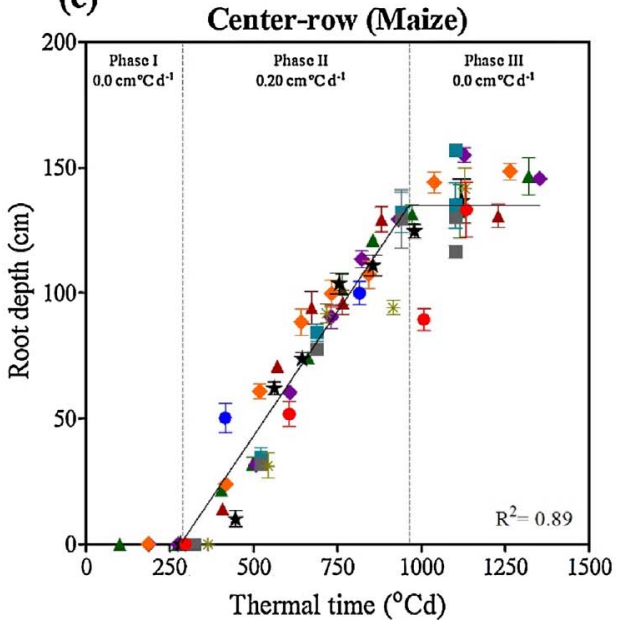

(b)

In-row (Soybean)

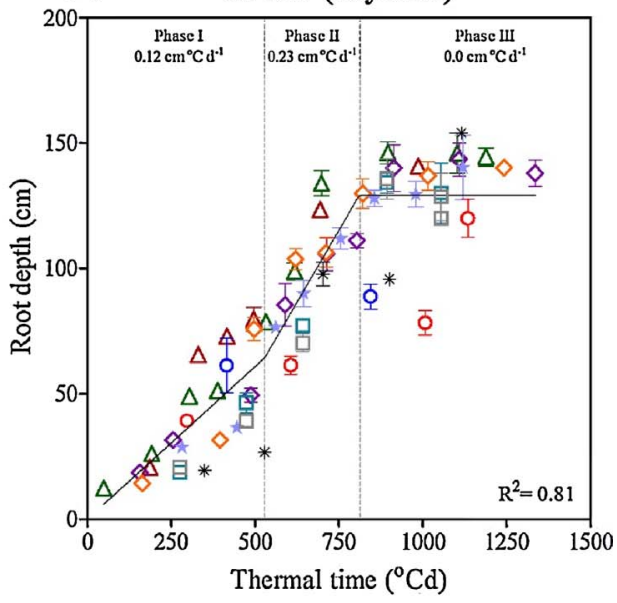

(d)

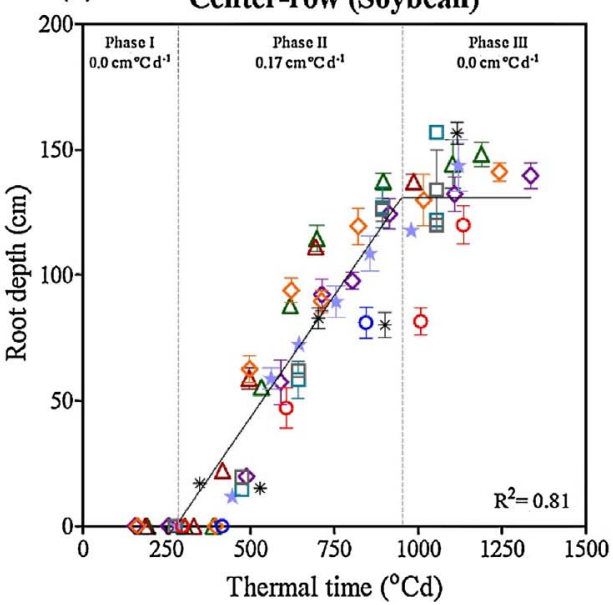

Fig. 5. Relationship between root depth and thermal time for maize and soybean crops in Iowa. Symbols explanations are provided in Table 1 . Solid lines are bi- and tri-linear model fits (parameter values per treatment are provided in Table S1).

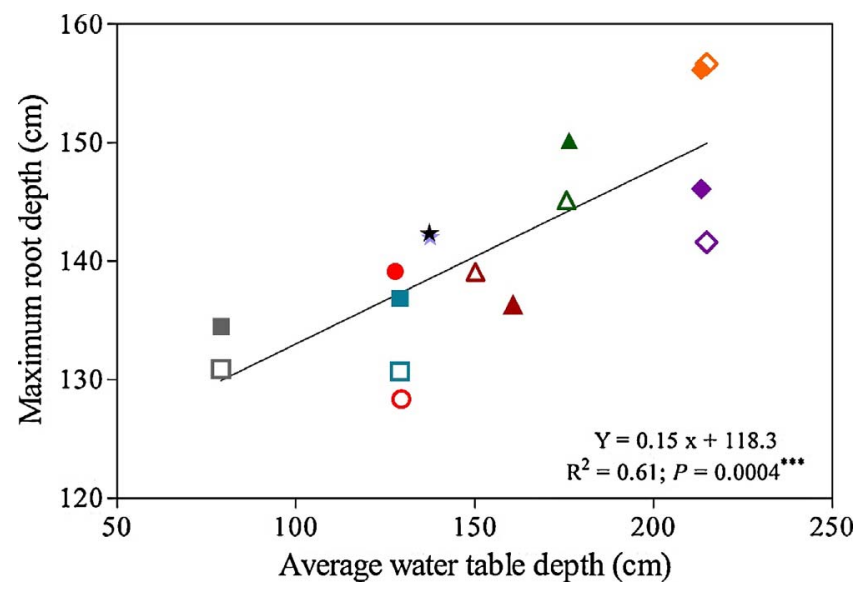

Fig. 6. Relationship between water table and the average of maximum root depth for maize and soybean across 16 field experiments. Water table data averaged two weeks prior to the final root measurements. Closed symbols represent maize and open symbols represent soybean. Symbols explanation is provided in Table 1.

2016; Sela et al., 2017), and benchmark management practices (Thorp et al., 2008; Wang et al., 2016) and climate change impacts (Wang et al., 2015; Paustian et al., 2016; Jin et al., 2017; Schauberger et al., 2017). To our knowledge, the validity of the root parameters used in the above modeling studies have not been evaluated. Our results can assist both calibration of model parameters as well as development of improved functions towards more accurate model simulations in this region. For instance linking RFV parameters to leaf number in corn and node number in soybean (Fig. 4) may improve the simulation of root depth and plant available water/nitrogen. Importantly our measurements revealed that the position of root measurement can greatly affect results and RFV parameters (Table 2).

\subsection{Time to cover the center-row and cease root growth}

Another important result from this study is the determination of the time needed for the root system to cover the space between $76 \mathrm{~cm}$ crop rows (6th leaf stage for maize; 40 days after planting; $450{ }^{\circ} \mathrm{Cd}$; Figs. 4 and S4). This information can support improved modeling of the root system and inform in-season nitrogen placement to maize. Rapid root growth into the center-row may explain the general lack of fertilizer banding effect on crop yield in the US Midwestern cropping areas (Randall and Hoeft, 1988; Mallarino et al., 1999).

The timing when root transition occurs from slow to fast rate of increase was related to leaf number (Figs. 3 and 4 and S3 and 4). The time when maize reached maximum depth was approximately at silking or 10 days before the start of grain filling, which is in agreement with previous reports (Dwyer et al., 1988; Liedgens et al., 2000; Fageria and Moreira, 2011). On average, soybean root elongation ceased before or at the onset of pod and grain accumulation (Figs. 4 and S4) with few exceptions (Fig. 3). We expected soybean roots to keep growing during grain filling and cease root elongation later than maize due to indeterminate growth pattern (Kaspar et al., 1978; Torrion et al., 2012). 
This might be explained by the short maturity cultivars used in Iowa (Table 1) and due to water table depth that might constrained further root growth (Fig. 6).

\subsection{Maximum root depth}

Our maximum depth observations for maize and soybean agree with earlier observations made in Iowa (Mitchell and Russell, 1971; Taylor and Keppler, 1973; Stone et al., 1976; Mason et al., 1982; Kaspar et al., 1984). This suggests that root traits have not changed over time (in contrast to plant traits; Duvick and Cassman, 1999; Ciampitti et al., 2012) given the 30 years difference between our study and previous measurements in Iowa. Compared to other environments our maximum depth measurements for both crops were different from other studies (range: 68-240 cm; Allmaras et al., 1975; Garay and Wilhelm, 1983; Canadell et al., 1996; Dardanelli et al., 1997; Araki et al., 2000; Qi et al., 2012; Gao et al., 2014). We believe the variation is due to interaction between genotypes, management and environment, and in particular due to two factors: cultivar length cycle and shallow water tables, and also soil temperature and moisture content (Reyes et al., 2015; van Oosterom et al., 2016). The fact that maize and soybean maximum root depth measurements were similar in this study (Table 2) might be attributed to the fact that roots cannot grow under saturated water conditions due to the lack of oxygen (Weaver, 1926; Stanley et al., 1980; Armstrong and Drew, 2002; van Oosterom et al., 2016) and therefore differences between crops could not be easily observed.

Many crop growth modelers work with the assumption that roots grow in a conical shape. For example, Yang et al. (2017) recently improved the Hybrid-Maize model from having a conical root shape to a uniform distribution until $30 \mathrm{~cm}$ followed by a conical root distribution to the bottom of the profile. In contrast, we found that roots occupy the full soil profile relatively quickly and there was no difference in maximum depths between these two sampling positions (Table 2). Our results suggest that maize and soybean roots is possible to take up water and nutrients from the entire profile in the study sites (Table 2). However, the root system shape and ability to extract water depends on the agronomic practices used (e.g. row configuration; Whish et al., 2005).

\subsection{Predictability of root growth and water table effects}

The strong correlation between root depth and easily measurable plant variables $\left(R^{2}>0.77\right)$ could be considered as useful information for root phenotyping in breeding programs (Fig. 5, Figs. S2 and S3) where root growth has been largely ignored. Thermal time was the best "easily measured" estimator for root elongation in line with our hypothesis (Fig. 5). However, in all correlations we found an increased variability in root elongation estimations at the deepest depths (see phase III in Fig. 5). About $61 \%$ of this variability was explained by water table depth in our study (Fig. 6), which confirms our initial hypothesis. This is a very important finding because it indicates that in addition to temperature, water table depth during the growing season should be considered for maximum root depth estimation in this environment, which is also common in many cropping areas at the Corn Belt regions in US. Most of the crop models applied in this region (see references above) estimate root depth as a function of temperature, in agreement with our results, but do not simulate water table depth and its impact on root and plant growth, which is another area for model improvement.

Literature studies have shown a 7-27\% maize yield increase with decreasing water table depth from $0.5 \mathrm{~m}$ to $1.5 \mathrm{~m}$ in Iowa (Ahmad and Kanwar, 1991; Kalita and Kanwar, 1992; Helmers et al., 2012) and an optimum water table depth for maximizing maize production in other environments (Florio et al., 2014). In our study we did not find a significant correlation between water table depth and yield $(P>0.30$; Fig. S5), but observed root depth variation in response to water table depth (Fig. 6). Crop yield response to water table is simply expression of root functioning in response to moisture conditions. More studies are needed to fully understand the mechanisms by which root water and nitrogen uptake as well as root senescence are affected by shallow water tables (e.g. Stanley et al., 1980; Dickin and Wright, 2008). This becomes even more important considering the increasing climate variability in this region (Dai et al., 2015) and the fact that in-season precipitation (35-year average: $498 \pm 20 \mathrm{~mm}$ ) is above the optimum amount found $(320-430 \mathrm{~mm})$ to maximize production and environmental performance of maize and soybean systems in Iowa (Dietzel et al., 2016).

\section{Conclusion}

This study provided new data on RFV and maximum depth for maize and soybean crops across six sites and 20 experimental treatments in Iowa, USA. Our results demonstrated that maize and soybean root systems had different RFV values early in the season but similar RFV values during the mid-season and reached about the same maximum depth in the study sites. For RFV we found two different rates of increase (early and late) during crop growth. Root system attributes such as time to reach maximum depth, time to reach the center of two rows, and time when RFV change rate from early to late phase were quantified and could be useful in process-based models to provide answers to practical management questions. The correlations between below-ground and above-ground plant traits could be useful to assist phenotyping in breeding programs. A particularly important result from this study was the significant correlation between maximum root depth and water table depth. Our results suggests that besides temperature that drives RFV, water table levels should also be taken into account for maximum root depth determinations in this environment, which is also common in many cropping areas at the Corn Belt region of the US.

\section{Acknowledgements}

This study was funded by the Iowa Soybean Association, Department of Agronomy, Plant Science Institute of Iowa State University, and USDA-NIFA Hatch project IOW03814. We thank Emily Marrs, Cooper Smith and Oluwakorede Olugbenle for their help in data collection.

\section{Appendix A. Supplementary data}

Supplementary data associated with this article can be found, in the online version, at http://dx.doi.org/10.1016/j.fcr.2017.09.003.

\section{References}

Ahmad, N., Kanwar, R.S., 1991. Effect of different moisture stress levels on corn growth in field lysimeters. Am. Soc. Agric. Eng. 34, 1991-1996.

Allmaras, R.R., Nelson, W.W., Voorhees, W.B., 1975. Soybean and corn rooting in southwestern Minnesota. II. Root distributions and related water inflow. Soil Sci. Soc. Am. Proc. 39, 771-777.

Araki, H., Hirayama, M., Hirasawa, H., Iijima, M., 2000. Which roots penetrate the deepest in rice and maize root systems? Plant Prod. Sci. 3, 281-288.

Archontoulis, S.V., Miguez, F.E., 2015. Nonlinear regression models and applications in agricultural research. Agron. J. 107, 786-798.

Armstrong, W., Drew, M.C., 2002. Root growth and metabolism under oxygen deficiency. In: Waisel, Y., Eshel, A., Kafkafi, U. (Eds.), Plant Roots: The Hidden Half (third Edition). Marcel Dekker, New York, pp. 729-761.

Ball-Coelho, B.R., Roy, R.C., Swanton, C.J., 1998. Tillage alters corn root distribution in coarse-textured soil. Soil Till. Res. 45, 237-249.

Bao, Y., Aggarwal, P., Robbins, N.E., Sturrock, C.J., Thompson, M.C., Tan, H.Q., Tham, C., Duan, L., Rodriguez, P.L., Vernoux, T., Mooney, S.J., Bennet, M.J., Dinneny, J.R., 2014. Plant roots use a patterning mechanism to position lateral root branches toward available water. Proc. Natl. Acad. Sci. 111, 9319-9324.

Boote, K.J., Sau, F., Hoogenboom, G., Jones, J.W., 2008. Experience with water balance, evapotranspiration, and predictions of water stress effects in the CROPGRO model. In: Ahuja, L.R., Reddy, V.R., Sassendran, S.A., Qiang, Yu (Eds.), Advances in Agricultural Systems Modeling 1, Response of Crops to Limited Water: Understanding and Modeling Water Stress Effects on Plant Growth Processes, http://dx.doi.org/10. 
2134/advagricsystmodel1.c3.

Borg, H., Grimes, D.W., 1986. Depth development of roots with time: an Empirical description. Am. Soc. Agric. Eng. 29, 194-197.

Cahn, M.D., Zobel, R.W., Bouldin, D.R., 1989. Relationship between root elongation rate and diameter and duration of growth of lateral roots of maize. Plant Soil 119, 271-279.

Canadell, J., Jackson, R.B., Ehleringer, J.B., Mooney, H.A., Sala, O.E., Schulze, E.D., 1996. Maximum rooting depth of vegetation types at the global scale. Oecologia 108, 583-595.

Ciampitti, I.A., Vyn, T.J., 2012. Physiological perspectives of changes over time in maize yield dependency on nitrogen uptake and associated $\mathrm{N}$ efficiencies: a review. Field Crops Res. 133, 48-67.

Comas, L.H., Becker, S.R., Cruz, V.M.V., Byrne, P.F., Dierig, D.A., 2013. Root traits contributing to plant productivity under drought. Front. Plant Sci. 4, 442.

Corre-Hellou, G., Brisson, N., Launay, M., Fustec, J., Crozat, Y., 2007. Effect of root depth penetration on soil nitrogen competitive interactions and dry matter production in pea-barley intercrops given different soil nitrogen supplies. Field Crops Res. 103, 76-85.

Dai, A., Fyfe, J.C., Xie, S.P., Dai, X., 2015. Decadal modulation of global surface temperature by internal climate variability. Nat. Clim. Change 5, 555-559.

Dardanelli, J.L., Bachmeier, O.A., Sereno, R., Gil, R., 1997. Rooting depth and soil water extraction patterns of different crops in a silty loam Haplustoll. Field Crops Res. 54, 29-38.

Dickin, E., Wright, D., 2008. The effects on winter waterlogging and summer drought on the growth and yield of winter wheat (Triticum aestivum L.). Eur. J. Agron. 28, 234-244.

Dietzel, R., Jarchow, M.E., Liebman, M., 2015. Above- and belowground growth biomass, and nitrogen use in maize and reconstructed prairie cropping systems. Crop Sci. 55, 910-923.

Dietzel, R., Liebman, M., Ewing, R., Helmers, M., Horton, R., Jarchow, M., Archontoulis, S., 2016. How efficiently do corn- and soybean based cropping systems use water? A systems modelling analysis. Glob. Change Biol. 22, 666-681.

Dunbabin, V., Diggle, A., Rengel, Z., 2003. Is there an optimal root architecture for nitrate capture in leaching environments? Plant Cell Environ. 26, 835-844.

Duvick, D.N., Cassman, K.G., 1999. Post-green revolution trends in yield potential of temperate maize in the North-Central United States. Crop Sci. 39, 1622-1630.

Dwyer, L.M., Stewart, D.W., Balchin, D., 1988. Rooting characteristic of corn, soybeans and barley as a function of available water and soil physical characteristics. Can. J. Soil Sci. 68, 121-132.

Dwyer, L.M., Ma, B.L., Stewart, D.W., Hayhoe, H.N., Balchin, D., Culley, J.L.B., McGovern, M., 1996. Root mass distribution under conventional and conservation tillage. Can. J. Soil Sci. 76, 23-28.

Fageria, N.K., Moreira, A., 2011. The role of mineral nutrition on root growth of crop plants. Adv. Agron. 110, 151-318 Chapter 4.

Feldman, L., 1994. The maize root. In: Freeling, M., Walbot, V. (Eds.), The Maize Handbook. Springer, New York, pp. 29-37.

Florio, E.L., Mercau, J.L., Jobbágy, E.G., Nosetto, M.D., 2014. Interactive effects of watertable depth, rainfall variation, and sowing date on maize production in the Western Pampas. Interact. Water Manage. 146, 75-83.

Gao, K., Chen, F.J., Yuan, L.X., Mi, G.H., 2014. Cell production and expansion in the primary root of maize in response to low-nitrogen stress. J. Integr. Agric. 13, 2508-2517.

Garay, A.F., Wilhelm, W., 1983. Root System Characteristics of two soybean isolines undergoing water stress condition. Agron. J. 75, 973-977.

Hammer, G.L., Dong, Z., Mclean, G., Doherty, A., Messina, C., Schussler, J., Zinselmeir, C., Paszkiewicz Cooper, M., 2009. Can changes in canopy and/root systems architecture explain historical maize yield trends in the US. Corn Belt? Crop Sci. 49, 299-312.

Helmers, M., Christianson, R., Brenneman, G., Lockett, D., Pederson, C., 2012. Water table, drainage, and yield response to drainage water management in southeast Iowa. J. Soil Water Conserv. 67, 495-501.

Hood-Nowotny, R., Umana, N.H.N., Inselbacher, E., Oswald-Lachouani, P., Wanek, W., 2010. Alternative methods for measuring inorganic, organic, and total dissolved nitrogen in soil. Soil Sci. Soc. Am. J. 74, 1018-1027.

Jin, Z., Zhuang, Q., Wang, J., Archontoulis, S.V., Zobel, Z., Kotamarthi, V.R., 2017. The combined and separate impacts of climate extremes on the current and future US rainfed maize and soybean production under elevated CO2. Glob. Change Biol. http://dx.doi.org/10.1111/gcb.13617.

Kalita, P.K., Kanwar, R.S., 1992. Shallow water table effects on photosynthesis and corn yield. Am. Soc. Agric. Eng. 35, 97-104.

Kashiwagi, J., Krishnamurthy, L., Purushothamanb, R., Upadhyaya, H.D., Gaur, P.M., Gowda, C.L.L., Itoc, O., Varshney, R.K., 2015. Scope for improvement of yield under drought through the root traits in chickpea (Cicer arietinum L.). Field Crops Res. 170, $47-54$.

Kaspar, T.C., Stanley, C.D., Taylor, H.M., 1978. Soybean root growth during the reproductive stages of development. Agro. J. 70, 1105-1107.

Kaspar, T.C., Taylor, H.M., Shibles, R.M., 1984. Taproot-elongation rates of soybean cultivars in the glasshouse and their relationship to field rooting depth. Crop Sci. 24, 917-924.

Kaspar, T.C., Brown, H.J., Kassmeyer, E.M., 1991. Corn root distribution as affected by tillage, wheel traffic and fertilizer placement. Soil Sci. Soc. Am. J. 55, 1390-1394.

Keating, B.A., Carberry, P.S., Hammer, G.L., Probert, M.E., Robertson, M.J., Holzworth, D., Huth, N.I., Hargreaves, J.N.G., Meinke, H., Hochman, Z., McLean, G., Verburg, K., Snow, V., Dimes, J.P., Silburn, M., Wang, E., Brown, S., Bristow, K.L., Asseng, S., Chapman, S., McCown, R.L., Freebairn, D.M., Smith, C.J., 2003. An overview of APSIM, a model designed for farming systems simulation. Eur. J. Agron. 18, 267-288.

Lazicki, P.A., Liebman, M., Wander, M.M., 2016. Root parameters show how management alters resource distribution and quality in conventional and low-input cropping systems in central Iowa. PLoS One 11, e0164209.

Lersten, N.R., Carlson, J.B., 2004. Vegetative morphology. In: Boerma, H.R., Specht, J.E. (Eds.), Soybeans: Improvement, Production, and Uses, Third ed. Agronomy Series No. 16 ASA, CSSA, SSSA, Madison, pp. 15-57.

Liedgens, M., Soldati, A., Stamp, P., Richner, W., 2000. Root development of maize (Zea mays L.) as observed with minirhizotrons in lysimeters. Crop Sci. 40, 1665-1672.

Logsdon, S.D., Hernandez-Ramirez, G., Hadfield, J.L., Sauer, T.J., Prueger, J.H., 2009. Soil water and shallow groundwater relations in an agricultural hillslope. Soil Sci. Soc. Am. J. 73, 1461-1468.

Lynch, J.P., 2007. Roots of the second Green revolution. Aust. J. Bot. 55, 493-512.

Lynch, J.P., 2013. Steep, cheap and deep: an ideotype to optimize water and $\mathrm{N}$ acquisition by maize root systems. Ann. Bot. 112, 347-357.

Mallarino, A.P., Bordoli, J.M., Borges, R., 1999. Phosphorus and potassium placement effects on early growth and nutrient uptake of no-till corn and relationships with grain yield. Agron. J. 91, 37-45.

Malone, R.W., Jaynes, D.B., Ma, L., Nolan, B.T., Meek, D., Karlen, D., 2010. Soil test N recommendation augmented with PEST-optimized RZWQM simulations. J. Environ. Qual. 39, 1711-1723.

Manschadi, A.M., Hammer, G.L., Christopher, J.T., DeVoil, P., 2008. Genotypic variation in seedling root architectural traits and implications for drought adaptation in wheat (Triticum aestivum L.). Plant Soil 303, 115-129.

Mason, W.K., Rowse, H.R., Bennie, A.T.P., Kaspar, T.C., Taylor, H.M., 1982. Response of soybeans to two row spacings and two soil water levels. II. Water use: root growth and plant water status. Field Crops Res. 5, 15-29.

Mayaki, W.C., Teare, D., Stone, L.R., 1976. Top and root growth of irrigated and nonirrigated soybeans. Crop Sci. 16, 92-94.

Meinke, H., Hammer, G.L., Want, P., 1991. Potential soil water extraction by sunflower on a range of soils. Field Crops Res. 32, 59-81.

Mitchell, R.L., Russell, W.J., 1971. Root development and rooting patterns of soybean (Glycine max (L.) Merill) evaluated under field conditions. Agron. J. 63, 313-316.

Monteith, J.L., 1986. How do crops manipulate water supply and demand? Phil. Trans. R. Soc. London B 316, 245-259.

Morell, F.J., Yan, H.S., Cassman, K.G., Van Wart, J., Elmore, R.W., Licht, M., Coulter, J.A., Ciampitti, I.A., Pittelkow, C.M., Brouder, S.M., Thomison, P., Lauer, J., Graham, C., Massey, R., Grassini, P., 2016. Can crop simulation models be used to predict local to regional maize yields and total production in the U.S. Corn Belt? Field Crop Res. 192, $1-12$.

Paez-Garcia, A., Motes, C.M., Scheible, W.R., Chen, R., Blancaflor, E.B., Monteros, M.J., 2015. Root traits and phenotyping strategies for plant improvement. Plants 4, $334-355$.

Passioura, J.B., 2006. The perils of pot experiments. Funct. Plant Biol. 33, 1075-1079.

Paustian, L., Lehmann, J., Ogle, S., Reay, D., Robertson, G.P., Smith, P., 2016. Climatesmart soils. Nature 532, 49-57.

Puntel, L.A., Sawyer, J.E., Barker, D.W., Dietzel, A., Poffenbarger, H., Castellano, M.J., Moore, K.J., Thorburn, P., Archontoulis, S.V., 2016. Modelling long-term corn yield response to nitrogen rate and crop rotation. Front. Plant Sci. 7, 1630.

Qi, W.Z., Liu, H.H., Liu, P., Dong, S.T., Zhao, B.Q., So, H.B., Li, G., Liu, H.D., Zhang, J.W., Zhao, B., 2012. Morphological and physiological characteristics of corn (Zea mays L.) roots from cultivars with different yields potentials. Eur. J. Agron. 38, 54-63.

Randall, G.W., Hoeft, R.G., 1988. Placement methods for improved efficiency of P and K fertilizers: a review. J. Prod. Agric. 1, 70-79.

Reyes, A., Messina, C.D., Hammer, G.L., Liu, L., van Oosterom, E., Lafitte, R., Cooper, M., 2015. Soil water capture trends over 50 years of single-cross maize (Zea mays L.) breeding in the US corn-belt. J. Exp. Bot. 66, 7339-7346.

Ritchie, J.T., NeSmith, D.S., 1991. Temperature and crop development. In: Hands, J., Ritchie, J.T. (Eds.), Modeling Plant and Soil Systems. Agronomy monographs No. 31, pp. 5-27.

Robertson, M.J., Fukai, S., Hammer, G.L., Ludlow, M.M., 1993. Modelling root growth of grain sorghum using the CERES approach. Field Crops Res. 33, 113-130.

Schauberger, B., Archontoulis, S., Arneth, A., Balkovic, J., Ciais, P., Deryng, D., Elliott, J., Folberth, C., Khabarov, N., Müller, C., Pugh, T.A.M., Rolinski, S., Schaphoff, S., Schmid, E., Wang, X., Schlenker, W., Frieler, K., 2017. Consistent negative response of US crops to high temperatures in observations and crop models. Nat. Commun. 8, 13931.

Schilling, K.E., 2007. Water table fluctuations under three riparian land covers, Iowa (USA). Hydrol. Proc. 21, 2415-2424.

Sela, S., van Es, H.M., Moebius-Clune, B.N., Marjerison, R., Moebius-Clune, D., Schindelbeck, R., Severson, K., Young, E., 2017. Dynamic model improves agronomic and environmental outcomes for maize nitrogen management over static approach. J. Environ. Qual. 46, 311-319.

Singh, V., van Oosterom, E.J., Jordan, D.R., Messina, C.D., Cooper, M., Hammer, G.L., 2010. Morphological and architectural development of root systems in sorghum and maize. Plant Soil 333, 287-299.

Soylu, M.E., Kucharik, C.J., Loheide II, S.P., 2014. Influence of groundwater on plant water use and productivity: development of an integrated ecosystem -variably saturated soil water flow model. Agric. For. Meteorol. 189, 198-210.

Stanley, C.D., Kaspar, T.C., Taylor, H.M., 1980. Soybean top and root response to temporary water tables imposed at three different stages of growth. Agron. J. 72, 341-346.

Stone, L.R., Teare, I.D., Nickel, C.D., Mayaki, W.C., 1976. Soybean root development and soil water depletion. Agron. J. 68, 677-680.

Taylor, H.M., Klepper, B., 1973. Rooting density and water extraction patterns for corn (Zea mays L.). Agron. J. 65, 965-968.

Thorp, K.R., DeJonge, K.C., Kaleita, A.L., Batchelor, W.D., Paz, J.O., 2008. Methodology for the use of DSSAT models for precision agriculture decision support. Comput. 
Electron. Agric, 64, 276-285.

Tollenaar, M., Lee, E.A., 2006. Dissection of physiology processes underlying grain yield in maize by examining genetic improvement and heterosis. Maydica 51, 399-408.

Tollenaar, M., Ahmadzadeh, A., Lee, E.A., 2004. Physiological basis for grain yield improvement in maize. Crop Sci. 44, 2086-2094.

Torrion, J.A., Setiyono, T.D., Cassman, K.G., Ferguson, R.B., Irmak, S., Specht, J.E., 2012. Soybean root development relative to vegetative and reproductive phenology. Agron. J. 104, 1072-1709.

USDA-NASS, 2015. Land Use Strata for Selected State. www.nass.usda.gov/Research and Science/stratafront2b.php.

van Oosterom, E.J., Yang, Z., Zhang, F., Deifel, K.S., Cooper, M., Messina, C.D., Hammer, G.L., 2016. Hybrid variation for root system efficiency in maize: potential links to drought adaptation. Funct. Plant Biol. 43, 502-511.

Wang, E., Smith, C.J., 2004. Modeling the growth and water uptake function of plant root systems: a review. Aust. J. Agric. Res. 55, 501-523.

Wang, C., Liu, W., Li, Q., Ma, D., Lu, H., Feng, W., Xie, Y., Zhu, Y., Guo, T., 2014. Effects of different irrigation and nitrogen regimes on root growth and its correlation with above-ground plant parts in high-yielding wheat under field conditions. Field Crops Res. 165, 138-149.

Wang, Z., Qi, Z., Xue, L., Bukovsky, M., Helmers, M., 2015. Modeling the impacts of climate change on nitrogen losses and crop yield in a subsurface drained field. Clim. Change 129, 323-335.

Wang, Z., Qi, Z., Xue, L., Bukovsky, M., 2016. RZWQM2 simulated management practices to mitigate climate change impacts on nitrogen losses and corn production. Environ. Modell. Softw. 84, 99-111.

Watt, M., Silk, W.K., Passioura, J.B., 2006. Rates of root and organism growth soil conditions, and temporal and spatial development of the rhizosphere. Ann. Bot. 97 839-855.

Weaver, 1926. Root Development of Field Crops. McGraw-Hill, New York.

Whish, J., Butler, G., Castor, M., Cawthray, S., Broad, I., Carberry, P., Hammer, G.L. McLean, G., Routley, R., Yeates, S., 2005. Modelling the effects of row configuration on sorghum yield reliability in north-eastern Australia. Aust. J. Agric. Res. 56, 11-23.

Wu, T.T., Li, J.Y., Wu, C.X., Sun, S., Mao, T.T., Jiang, B.J., Hou, W.S., Han, T.F., 2015. Analysis of the independent- and interactive-photo-thermal effects on soybean flowering. J. Integr. Agric. 14, 622-632.

Yang, H., Grassini, P., Cassman, K.G., Aiken, R.M., Coyne, P.I., 2017. Improvements to the hybrid-maize model for simulating maize yields in harsh rainfed environments. Field Crops Res. 204, 180-190.

York, L.M., Lynch, J.P., 2015. Intensive field phenotyping of maize (Zea mays L.) root crowns identifies phenes and phene integration associated with plant growth and nitrogen acquisition. J. Exp. Bot. 66, 5493-5505.

Yu, P., White, P.J., Hochholdinger, F., Li, C., 2014. Phenotypic plasticity of the maize root system in response to heterogeneous nitrogen availability. Planta 240, 667-678.

Zhang, Y.K., Schilling, K.E., 2006. Effects of land cover on water table, soil moisture, evapotranspiration and groundwater recharge: a field observation and analysis. J. Hydrol. 319, 328-338. 